\title{
Molecular Variability in Isolates of Rhizoctonia bataticola Causing Root Rot in Chickpea Using RAPD Markers
}

\author{
Archana A. Gadekar*, Epsita Swain and S.S. Mane \\ Department of Plant Pathology, Dr. Panjabrao Deshmukh Krishi Vidyapeeth, \\ Akola (M.S) 444 104, India \\ *Corresponding author
}

\section{A B S T R A C T}

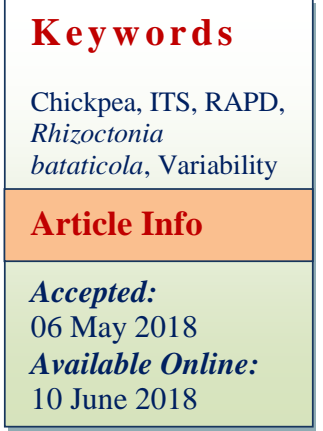

Dry root rot caused by Rhizoctonia bataticola (Taub.) Butler is emerging as a serious biotic constraint for chickpea production. It is soil borne fungal pathogen. The losses in chickpea due to Rhizoctonia bataticola may be as high as 60 per cent. The eight isolates of Rhizoctonia bataticola were collected from different districts of Maharashtra. The genomic DNA of 8 isolates of Rhizoctonia bataticola isolated from fresh mycelium of fungus grown in Potato Dextrose Broth solution and subjected to amplification with RAPD marker for diversity analysis. Amplified product of RAPD were resolved by electrophoresis and photographed under gel documentation system. Randomly selected 10 decamer primer amplified 101 RAPD marker loci. Out of these 101 bands, 85 bands (84.16 $\%)$ were polymorphic. Similarity coefficient values for 8 accessions of Rhizoctonia bataticola using RAPD markers was $0.35-0.73$. The RAPD banding pattern reflected the genetic diversity among the isolates by formation of two clusters.

\section{Introduction}

Chickpea (Cicer arietinum L.) is one of the major grain legumes widely grown in India as well as other parts of the world.

Among various factors attributing to low productivity of chickpea, susceptibility to diseases is very important. Chickpea is prone to many diseases and among them dry root rot caused by Rhizoctonia bataticola (Taub) Butler [Synonym - Macrophomina phaseolina (Tassi) Goid] is one of the major constraints in chickpea production and causing 10-60\% annual loss (Dhar and Chaudhary, 2001; Subramanian Sundravandana et al., 2012).
Rhizoctonia bataticola is primarily seed and soil-borne fungal pathogen. The pathogen also has wide host range. High day temperature above $30^{\circ} \mathrm{C}$ and dry soil conditions at flowering and podding stages rapidly increase the severity of the dry root rot disease on chickpea (Mamta Sharma et al., 2015).

Prolonged saprophytic survival ability of the pathogen in soil makes chemical control and crop rotation ineffective. Cultivation of resistance varieties is an economical approach for the management of dry root rot of chickpea, but only a few sources with low level of genetic resistance are available. The information regarding diversity among the 
populations of the pathogen should enhance the development and release of disease resistant chickpea cultivars. Different molecular methods such as random amplified polymorphic DNA (RAPD) have been used to reveal genetic polymorphism within populations of Rhizoctonia bataticola.

The objective of this study was to analyse the molecular variability among isolates of Rhizoctonia bataticola obtained from different chickpea growing districts of Maharashtra using RAPD markers.

\section{Materials and Methods}

\section{Fungal cultures}

Total eight isolates of Rhizoctonia bataticola were collected from different chickpea growing regions of Maharashtra covering districts including Akola, Nagpur, Amravati, Satara, Sangli, Kolhapur. Isolation was made by plating surface sterilized $(0.8 \%$ sodium hypochlorite for $2 \mathrm{~min}$ ) pieces from dry root rot infected roots of the chickpea plants on potato dextrose agar (PDA) medium. Inoculated plates were incubated at $25 \pm 2^{0} \mathrm{C}$ for colony growth. The cultures were purified by single sclerotial isolation and on the basis of morphological characters (mycelium and sclerotia) the isolates were identified as Rhizoctonia bataticola. The cultures were maintained on PDA slant at $4^{0} \mathrm{C}$ for further study (Table 1).

\section{Pathogenicity test}

The pathogenicity test of eight isolates of the pathogen was determined by modified sick soil method on chickpea cultivar JG-62 (Jayalakshmi et al., 2008). Surface sterilized ( $0.1 \%$ formalin) plastic pots were filled with autoclaved soil (three consecutive sterilization for 3 days at $104 \mathrm{kPa}$ for $1 \mathrm{~h}$ ) and inoculated 5 days prior to sowing with 15 days old inoculum $(25 \mathrm{~g} / \mathrm{kg})$ multiplied on sand maize meal media. Sand and ground maize seeds were mixed in a ratio of 3:1 moistened to $50 \%$ moisture content, filled in $250 \mathrm{ml}$ conical flasks (100 g/flask). The flasks containing sand maize meal media were autoclaved for two subsequent days at $104 \mathrm{kPa}$ for $30 \mathrm{~min}$ and inoculated with 3 day old culture of Rhizoctonia bataticola. Inoculated flasks were incubated at $25 \pm 1^{0} \mathrm{C}$ for 15 days. Ten seeds of chickpea variety JG-62 were sown in each pot in three replications and observed for symptoms development. Re-isolation was made from the roots of diseased plants on PDA medium and isolated fungus was identified to confirm its identity. The per cent emergence and post-emergence mortality at 30 days after sowing was recorded and total mortality was calculated.

\section{DNA extraction}

The isolates were grown in potato dextrose broth medium at $25 \pm 1{ }^{0} \mathrm{C}$ for 10 days. Mycelia were harvested by filtering through Whatman filter Paper No. 1, washed repeatedly with distilled sterilized water. DNA extraction was based on the cetrimide tetradecyl trimethyl ammonium bromide (CTAB) method (Murray and Thompson 1980). Mycelium (1 g) was crushed in liquid nitrogen and transferred into $2 \mathrm{ml}$ pre-warmed DNA extraction buffer $\left[1 \mathrm{M}\right.$ Tris- $\mathrm{HCl}\left(\mathrm{p}^{\mathrm{H}}\right.$ 8.0), $5 \mathrm{M} \mathrm{NaCl}, 0.5 \mathrm{M}$ EDTA ( $\mathrm{pH}$ 8.0) and $2 \% \mathrm{CTAB}]$, mixed well and incubated in a water bath at $65^{\circ} \mathrm{C}$ with gentle shaking for $1 \mathrm{~h}$. Equal volume of chloroform : isoamyl alcohol $(24: 1 \mathrm{v} / \mathrm{v})$ was added and mixed gently to denature proteins and centrifuged at $12,857 \mathrm{~g}$ for 10 min. DNA was precipitated with 0.6 volume of chilled isopropanol was again centrifuged at $18,514 \mathrm{~g}$ for $15 \mathrm{~min}$. The pellets were washed twice with chilled $70 \%$ ethanol, dried at room temperature, re-suspended in $100 \mu \mathrm{l}$ sterile TE $(10 \mathrm{mMTris}-\mathrm{HCl}$ buffer and $1 \mathrm{mM}$ EDTA- $\mathrm{pH} 8$ ) and stored at $-20^{\circ} \mathrm{C}$. 
Isolated DNA was electrophorased in $0.8 \%$ agarose gels to check the quality and concentration.

\section{ITS (Internal transcribed spacer)}

The ITS primer pair ITS 1 (5' TCCGTAGGTGAACCTGCGG 3') and ITS 4 (5' TCCTCCGCTTATTGATATGC 3') were used to screened all the 8 isolates of pathogen. The PCR reaction contained $50 \mathrm{ng}$ genomic DNA, 1X PCR buffer, $1.5 \mathrm{mM} \mathrm{MgCl}_{2}, 0.2$ $\mathrm{mM}$ dNTPs, $0.25 \mu \mathrm{M}$ of each primer and 1.0 $\mathrm{U}$ Taq DNA Polymerase in $50 \mu \mathrm{l}$ reaction volume. The PCR program was: Initial denaturation of $94^{\circ} \mathrm{C}$ for 5 min was followed by 35 cycles of $94^{\circ} \mathrm{C}$ for $1 \mathrm{~min}, 55^{\circ} \mathrm{C}$ for $1 \mathrm{~min}$ (primer annealing), $72^{\circ} \mathrm{C}$ for $2 \mathrm{~min}$ (primer extension). A final extension of $72^{\circ} \mathrm{C}$ for 5 min was incorporated into the program, followed by cooling to $4^{0} \mathrm{C}$ until recovery of the samples. PCR products were visualized using UV light and separated on $1.2 \%$ agarose gel pre-stained with ethidium bromide (1 $\mu \mathrm{g} / \mathrm{ml}) .100 \mathrm{~kb}$ ladder was used as a marker (Aghakhani and Dubey, 2009).

\section{Random Amplified Polymorphic DNA (RAPD) marker analyses}

Random Amplified Polymorphic DNA analysis of Rhizoctonia bataticola was done by using decamer nucleotide primer obtained from "Genaxy" (Williams et al., 1990). PCR was performed in Temperature Gradient Thermal Cycler (BioRAD, USA). Reactions were carried out in a final volume of $20 \mu \mathrm{l}$ containing 1X PCR buffer, 1 U Taq polymerase, $2.5 \mathrm{mM} \mathrm{MgCl} 2,0.6 \mathrm{mM}$ dNTPs, 9 pmolprimer and $75 \mathrm{ng}$ DNA. The PCR amplification was performed using following thermal cycling conditions: initial denaturation for $1 \mathrm{~min}$ at $94^{\circ} \mathrm{C}$, followed by 35 cycles of denaturation at $94^{\circ} \mathrm{C}$ for 1 min, annealing at $34^{\circ} \mathrm{C}$ for $1 \mathrm{~min}$, extension at $72^{\circ} \mathrm{C}$ for $2 \mathrm{~min}$. and final extension at $72^{\circ} \mathrm{C}$ for $7 \mathrm{~min}$ after completion of the cycles the samples were kept at $4^{0} \mathrm{C}$ until recovery of the samples. The annealing temperature $\left(34^{\circ} \mathrm{C}\right)$ was found to be the best for most of the primers included in the present study. Amplified products $(10 \mu \mathrm{l})$ were mixed with $3 \mu \mathrm{l}$ of $6 \mathrm{X}$ loading dye and analyzed by electrophoresis on $1 \%$ agarose gel containing $1 \mu \mathrm{g} / \mathrm{ml}$ of ethidium bromide in $1 \mathrm{X}$ TBE buffer ( $\mathrm{pH}$ 8.0) along with a $1 \mathrm{~kb}$ DNA ladder as standard molecular weight marker and visualized under ultraviolet light (Bio Rad gel doc system).

The primer that produced reproducible and scorable amplification was used in the analysis. DNA bands that could be scored unequivocally for their presence or absence were included in the analysis. Binary matrices were analyzed by NTSYS-PC (Version 2.02; Exeter Biological Software). Jaccard's coefficients were clustered to generate a dendrogram using SHAN clustering programme selecting unweighted paired group method with arithmetic averages (UPGMA) (Table 2 and 3).

\section{Results and Discussion}

\section{Pathogenicity test}

The isolates of the pathogen proved pathogenic on chickpea cultivar JG-62. Out of eight isolates, six isolates causing $21-50 \%$ dry root rot incidence were moderately pathogenic. These, six isolates, namely, $\mathrm{Rb}-1$ (Akola), Rb-2 (Nagpur), Rb-4 (Umbraj), Rb-5 (Karanje), Rb-6 (Sangli) and Rb-8 (Kini). Two isolates causing 51-70 \% dry root rot incidence were considered as strongly pathogenic. These two isolates, namely, Rb-3 (Amravati) and Rb-7 (Kurundwad).

\section{ITS}

PCR amplification with primer set ITS-1 and ITS-4 yielded single DNA fragment, present in all isolates with $\sim 500$ bp in size. 
Table.1 Details of isolates of Rhizoctonia bataticola used in the present study and dry root rot incidence caused by them in chickpea cultivar JG-62

\begin{tabular}{|l|}
\hline Sr. No. \\
\hline 1 \\
\hline 2 \\
\hline 3 \\
\hline 4 \\
\hline 5 \\
\hline 6 \\
\hline 7 \\
\hline 8 \\
\hline
\end{tabular}

\begin{tabular}{|l|l|}
\hline Isola & Rb-1 \\
\hline Rb-2 \\
\hline Rb-3 \\
\hline Rb-4 \\
\hline Rb-5 \\
\hline Rb-6 \\
\hline Rb-7 \\
\hline Rb-8 \\
\hline
\end{tabular}

\section{Place of collection}

Akola

Nagpur

Amravati

Umbraj (Satara)

Karanje (Satara)

Sangli

Kurundwad (Sangli)

Kini (Kolhapur)

\section{Dry root rot incidence (\%)} 44.00 50.00 57.69

48.14

48.00

43.47

52.00

39.13

Table.2 List of RAPD primers used with their sequences

\begin{tabular}{|l|l|l|l|}
\hline Sr. No. & Primer Screened & Sequence & Annealing Temp. $\left({ }^{\circ} \mathrm{C}\right)$ \\
\hline $\mathbf{1}$ & OPA-2 & TGCCGAGCTG & 34 \\
\hline $\mathbf{2}$ & OPA-5 & AGGGGTCTTG & 32 \\
\hline $\mathbf{3}$ & OPA-7 & GAAACGGGTG & 32 \\
\hline $\mathbf{4}$ & OPA-9 & GGGTAACGCC & 34 \\
\hline $\mathbf{5}$ & OPA-10 & GTGATCGCAG & 32 \\
\hline 6 & OPA-13 & CAGCACCCAC & 34 \\
\hline $\mathbf{7}$ & OPA-17 & GACCGCTTGT & 32 \\
\hline $\mathbf{8}$ & OPB-11 & GTAGACCCGT & 32 \\
\hline 9 & OPB-14 & TCCGCTCTGG & 34 \\
\hline 10 & OPF-4 & GGTGATCAGG & 32 \\
\hline
\end{tabular}

Table.3 Per cent polymorphism observed in RAPD primers

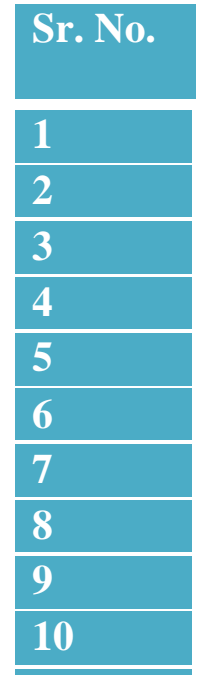

Total

\begin{tabular}{|l|l|l|}
\hline Bands & $\begin{array}{l}\text { Polymorphic } \\
\text { bands }\end{array}$ & $\%$ polymorphism \\
\hline 13 & 11 & 84.62 \\
\hline 9 & 8 & 88.89 \\
\hline 12 & 9 & 75 \\
\hline 10 & 9 & 90 \\
\hline 11 & 9 & 81.82 \\
\hline 13 & 10 & 76.92 \\
\hline 6 & 6 & 100 \\
\hline 14 & 11 & 78.57 \\
\hline 6 & 5 & 83.33 \\
\hline 7 & 7 & 100 \\
\hline $\mathbf{1 0 1}$ & $\mathbf{8 5}$ & $\mathbf{8 4 . 1 6}$ \\
\hline
\end{tabular}

1035 
Table.4 Similarity coefficient for RAPD analysis

\begin{tabular}{|l|l|l|l|l|l|l|l|l|}
\hline & $\mathbf{R b}-1$ & $\mathbf{R b}-2$ & $\mathbf{R b}-3$ & $\mathbf{R b}-4$ & $\mathbf{R b}-5$ & $\mathbf{R b}-6$ & $\mathbf{R b}-7$ & $\mathbf{R b}-8$ \\
\hline $\mathbf{R b}-1$ & 1.00 & & & & & & & \\
\hline $\mathbf{R b}-2$ & 0.44 & 1.00 & & & & & & \\
\hline $\mathbf{R b}-3$ & 0.37 & 0.47 & 1.00 & & & & & \\
\hline $\mathbf{R b}-4$ & 0.35 & 0.39 & 0.59 & 1.00 & & & & \\
\hline $\mathbf{R b}-5$ & 0.37 & 0.35 & 0.50 & 0.73 & 1.00 & & & \\
\hline $\mathbf{R b}-6$ & 0.36 & 0.45 & 0.45 & 0.43 & 0.51 & 1.00 & & \\
\hline $\mathbf{R b}-7$ & 0.47 & 0.41 & 0.37 & 0.41 & 0.45 & 0.42 & 1.00 & \\
\hline $\mathbf{R b}-8$ & 0.50 & 0.52 & 0.43 & 0.45 & 0.47 & 0.41 & 0.51 & 1.00 \\
\hline
\end{tabular}

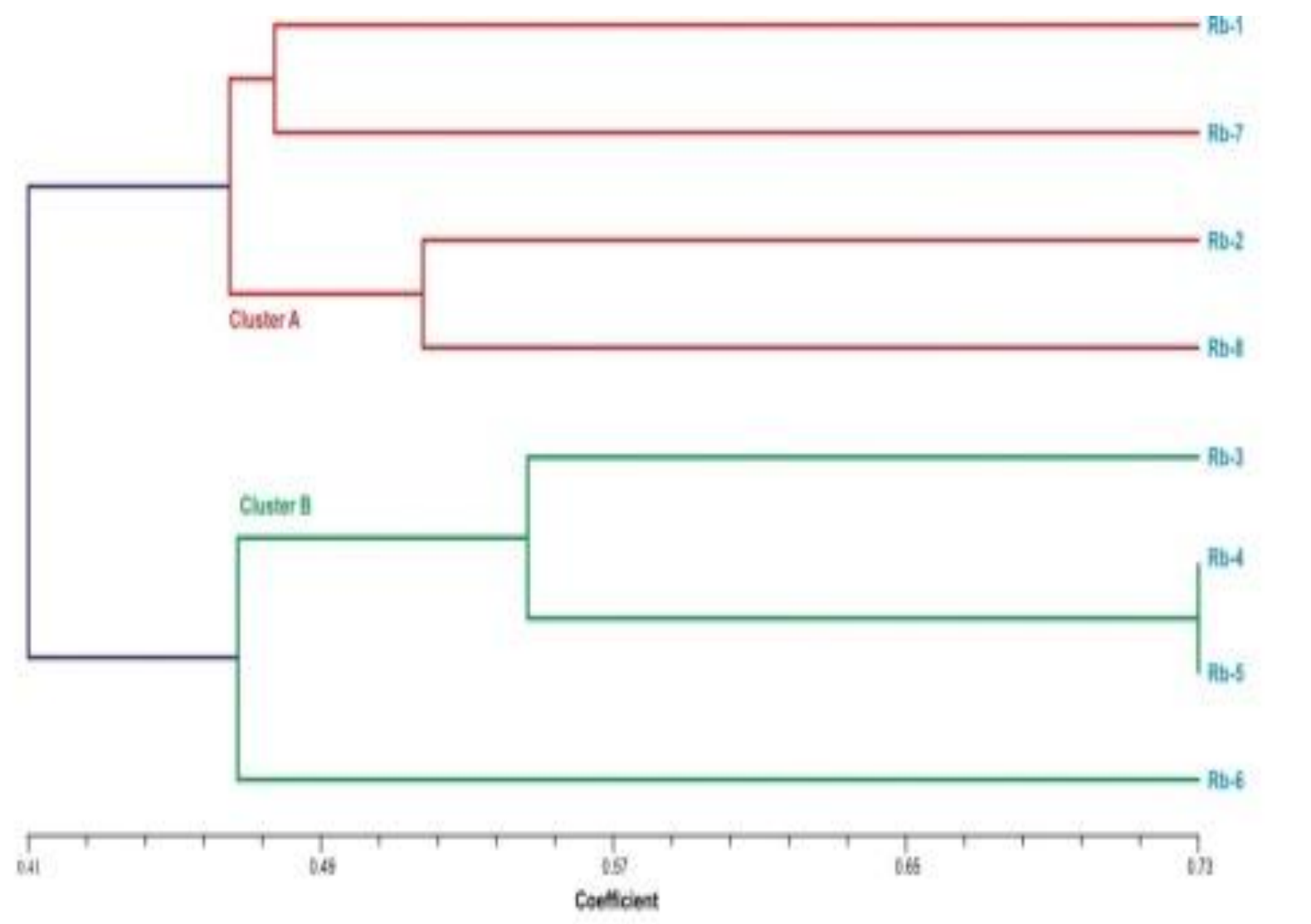

Fig. 1. The RAPD UPGMA dendrogram of eight isolates of Rhizoctonia bataticola based on Jaccard's similarity coefficient 


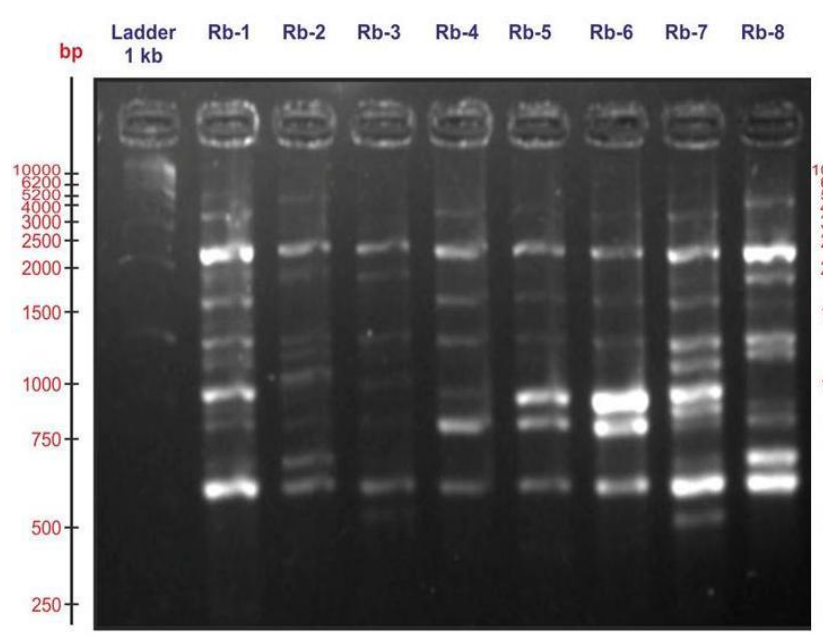

RAPD banding pattern of primer OPA-7

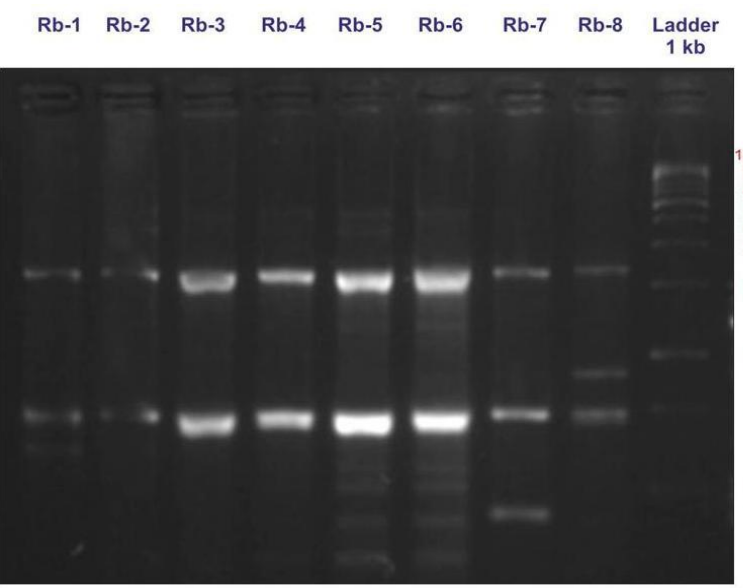

RAPD banding pattern of primer OPA-10

\section{RAPD analysis}

Genetic diversity analysis was the first step in any research programme. Molecular diversity analysis required a large number of polymorphic markers. Molecular marker represented very effective tool for analysis of molecular diversity in any research programme. The current investigation was undertaken to find out genetic relationship among 8 isolates of Rhizoctonia bataticola, causal agent of dry root rot in chickpea using RAPD markers.

Genetic variation was detected among 8 isolates of Rhizoctonia bataticola using 10 RAPD primers. Among 10 primers used for

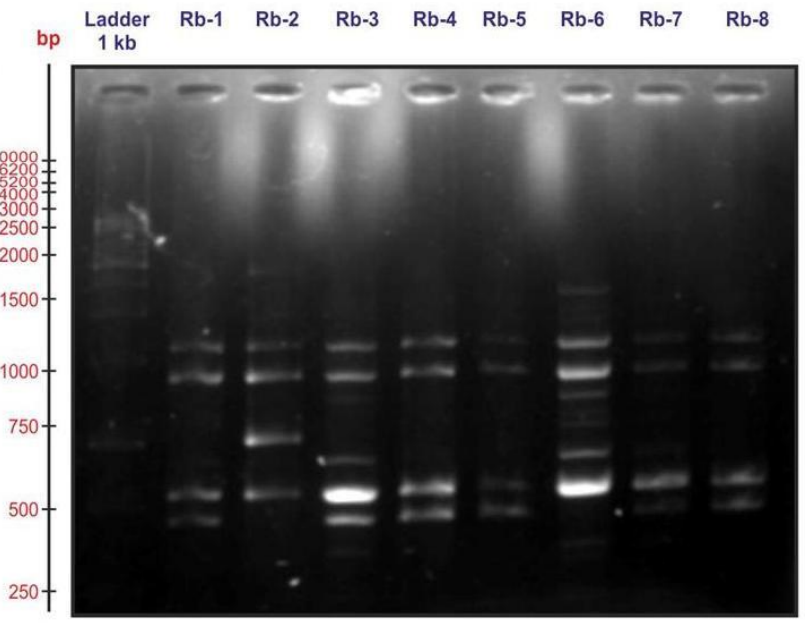

RAPD banding pattern of primer OPB-14

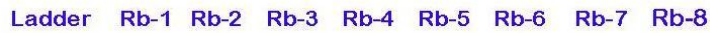

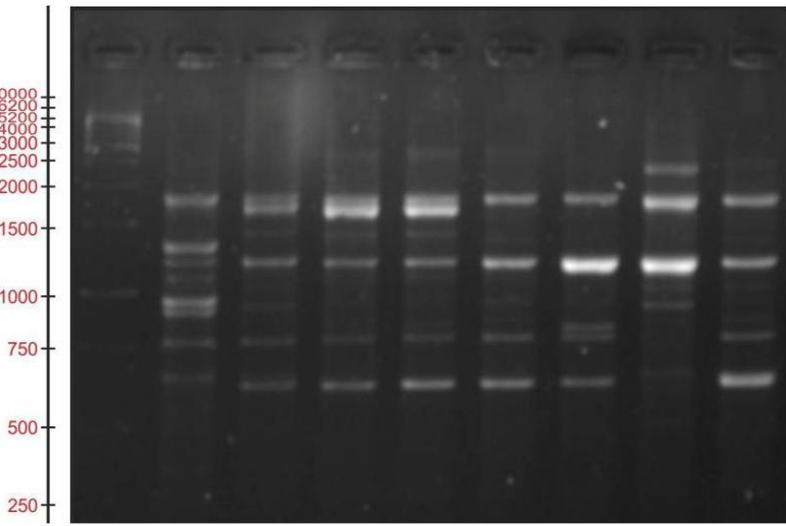

RAPD banding pattern of primer OPA- 13

amplification OPB-11 and OPA-17 showed cent per cent polymorphism among isolates. A total of 101 amplicon levels resulted from 10 primers and were available for analysis. Information on banding pattern for all the primers was used to determine genetic distance between isolates and to construct a dendrogram.

Based on Jaccard's coefficients, a genetic similarity matrix was constructed to assess the genetic relatedness among the isolates of Rhizoctonia bataticola. Genetic similarity coefficient of 8 isolates of Rhizoctonia bataticola based on RAPD analysis is given in the Table 4 . The range of genetic similarity based on RAPD primers was 0.35 to 0.73 . 
Isolate Rb-4 had high value of similarity coefficient (0.73) to isolate $\mathrm{Rb}-5$. This is indication of similarity between these isolates and have high similarity index as compared to others. Also, isolate $\mathrm{Rb}-1$ had lower value of similarity coefficient $(0.35)$ to isolate $\mathrm{Rb}-4$ which indicates least similarity between them. A dendrogram was generated by unweighted pair group method with "UPGMA" sub programme of "NTSYS-PC". The dendrogram for pooled data showed two major clusters (Fig. 1). The isolates Rb-1 (Akola), Rb-7 (Kurundwad), Rb-2 (Nagpur), $\mathrm{Rb}-8$ (Kini) were found in one cluster named as cluster- $\mathrm{A}$, isolates $\mathrm{Rb}-3$ (Amravati), $\mathrm{Rb}-4$ (Umbraj), Rb-5 (Karanje) and Rb-6 (Sangli) were found in second cluster named as cluster-B.

The aim of the present study was to assess the genetic diversity among 8 isolates of Rhizoctonia bataticola obtained from different chickpea growing states of Maharashtra using PCR based markers. All the isolates proved pathogenic on chickpea cultivar JG-62. Rb-3 and Rb-7 were strongly pathogenic and remaining isolates were moderately pathogenic. Aghakhani and Dubey (2009) conducted pathogenicity test of twenty-three isolates of Rhizoctonia bataticola (Macrophomina phaseolina) causing dry root rot of chickpea collected from 10 different major chickpea growing states of India. Highly susceptible cultivar Pusa 212 was susceptible and all the isolates were pathogenic under artificially inoculated conditions.

It is difficult to distinguish these species using traditional morphological and cultural differences. To understand better, the existence of variation among the isolates of Rhizoctonia bataticola, PCR based technique, i.e. RAPD (Random Amplified Polymorphic DNA) was used in the present investigation. The suitability of RAPD was used to detect the variations among the isolates of Rhizoctonia bataticola. OPB-11 and OPA-17 showed cent per cent polymorphism and OPA-2, OPA-5, OPA-9, OPA-10, OPF-4 showed more than 80 per cent polymorphism among isolates.

The dendrogram by RAPD data revealed that, the selected 8 isolates were differentiated into two major clusters, cluster-A and cluster-B. Similar studies were conducted by Rajkumar et al., (2007) also studied the genetic variability in ten isolates of Macrophomina phaseolina using PCR-RAPD markers. UPGMA clustering of data indicated that, the isolates shared varied levels of genetic similarity within a range of 0.14 to 0.72 similarity coefficient index and it was suggested that grouping of isolates was not related to sampling location in anyway. Pancheshwar et al., (2012) isolated the genomic DNA of 21 isolates of Rhizoctonia bataticola and genetic diversity was analysed by RAPD markers. The range of genetic diversity was 0.69-0.98. Belkar and Gade (2016) isolated the genomic DNA of 20 isolates of Rhizoctonia bataticola and subjected to amplification with RAPD markers for diversity analysis. The range of genetic diversity was 0.36-0.99.

\section{References}

Aghakhani, M., and Dubey S.C. 2009. Determination of genetic diversity among Indian isolates of Rhizoctonia bataticola causing dry root rot of chickpea. Antonie van Leeuwenhoek. 96: 607-619.

Belkar, Y. K., and Gade R. M. 2016. Molecular Variability of Rhizoctonia bataticola Causing Root Rot of Soybean Using RAPD Marker. Advances in Life Sciences 5(10): 42174224. 
Dhar, V., and Chaudhary R. G. 2001. Disease resistance in pulse crop current status and future approaches. In Nagarajan S., Singh D. P. (ed.), The Role of Resistance in Intensive Agriculture, New Delhi. Kalyani. Pp. 144-157.

Jayalakshmi, S. K., S. Usharani, V. I. Benagi and Mannur D.M. 2008. Sources of resistance to dry root rot of chickpea caused by Rhizoctonia bataticola. Agric. Sci. Digest. 28(2): 147-148.

Mamta Sharma, R. Ghosh and Pande S. 2015. Dry root rot (Rhizoctonia bataticola (Taub.) Butler): an emerging disease of chickpea - where do we stand? Archives of Phytopathology and Plant Protection, 48(13-16), 797-812.

Murray, M. G., and Thompson W. F. 1980.Rapid isolation of high molecular weight DNA. Nucleic Acid Res., 8: 4321-4325.

Pancheshwar, D. K., R. K. Varma, P. K. Gupta and Gharde Y. 2012. Molecular variability of Rhizoctonia bataticola causing charcoal root rot of soybean using RAPD marker. Annals of Plant Protection Sciences. 20 (1): 148-153.

Rajkumar, F. B., and Kuruvinashetti M. S. 2007. Genetic variability of Sorghum charcoal rot pathogen (Macrophomina phaseolina) assessed by random DNA markers. Plant Pathol. J. 23(2): 45-50.

Sundravandana, S., D. Alice and Thirumurugan S. 2012. Exploration of variability in colony morphology and virulence of Rhizoctonia bataticola isolates causing dry root rot of pulses. Global Journal of Bio-Science and Biotechnology. 1(1): 91-97.

Williams, J. G. K., A. R. Kubelik, K. J. Livak, J. A. Racalski and Tingey S. V. 1990. Oligonucleotide primers of arbitrary sequence amplify DNA polymorphism which are useful as genetic markers. Nucleic Acid Res., 18: 6531-6535.

\section{How to cite this article:}

Archana A. Gadekar, Epsita Swain and Mane, S.S. 2018. Molecular Variability in Isolates of Rhizoctonia bataticola Causing Root Rot in Chickpea Using RAPD Markers. Int.J.Curr.Microbiol.App.Sci. 7(06): 1032-1039. doi: https://doi.org/10.20546/ijcmas.2018.706.122 